\title{
Think Tank
}

\section{Radmila Gaćeša}

e-mail: radmila.gacesa@gmail.com

Prevod obezbedio autor
Rezime: Think tank predstavlja globalni fenomen savremenog sveta. Na svetskom nivou, od preko 6.300 think tank institucija koje su postojale 2009. godine, više od polovine je osnovano posle 1989. godine. Tom povećanju značajno je doprinela inostrana finansijska podrška za kreiranje think tank institucija u istočnoj Evropi.

Think tank institucije se između sebe razlikuju prema ideološkom pristupu, izvorima finansiranja, temama, odnosno oblastima kojima se bave, kao i prema korisnicima svojih usluga. Think tank institucije se, generalno posmatrano, nadmeću za uticaj u sferi politike, biznisa, nauke, medija i društva.

Dominantan broj think tank institucija se bavi temama iz politike, socijalne politike, sfere ekonomije i biznisa, integracija i slično. Pri tome je sve veći broj think tank institucija koje su posvećene socijalnim i ekološkim temama.

Brojnost think tank institucija, njihova globalna rasprostranjenost kao i trendovi daljeg razvoja upućuju na veliku zainteresovanost stručne i šire javnosti za njihovo angažovanje, domete i perspektivu.

Ključne reči: think tank, politike, istraživanja, fondacije, energija, vlade, javnost, lobiranje, klima

JEL: 100, Q40, Q50, Y80 
Think tank predstavlja globalni fenomen savremenog sveta. Sam pojam "think tank" je nastao u toku II svetskog rata i obuhvatio je dve odrednice: mesto koje je bezbedno za vođenje razgovora, dakle bez rizika u pogledu prisluškivanja (eng. tank - rezervoar) i na kome su civilni i vojni eksperti zajedno radili na vojnim strategijama (eng. think - misliti, razmišljati).

Tokom 60-tih i 70-tih godina 20. veka počele su da se ovim pojmom označavaju istraživačke institucije, koje su orijentisane na praksu izvan okvira nezbednosne politike. $U$ takve aktivnosti spadaju predstavljanje rezultata istraživanja, kao i utvrđivanje postavki programa delovanja i propagiranje odabranih tema, među kojima su najviše fokusirane sledeće: socijalna politika, ekonomija, politička strategija, tehnologija, bezbednost, klima, kultura i neke druge.

Globalno posmatrano, od preko 6.300 think tank institucija koje su postojale 2009. godine, više od polovine je osnovano posle 1989. godine. Tom povećanju značajno je doprinela inostrana finansijska podrška za kreiranje think tank institucija u Istočnoj Evropi.

Think tank institucije se između sebe razlikuju prema ideološkom pristupu, izvorima finansiranja, temama, odnosno oblastima kojima se bave, kao i prema korisnicima svojih usluga. Think tank institucije se, generalno posmatrano, nadmeću za uticaj u sferi politike, biznisa, nauke, medija i društva.

Dominantan broj think tank institucija se bavi temama iz politike, socijalne politike, sfere ekonomije i biznisa, integracija i slično. Pri tome je sve veći broj think tank institucija koje su posvećene socijalnim i ekološkim temama. Među njima se posebno ističe Tellus Institute, neprofitna institucija sa sedištem u Kembridžu, država Masačusets, SAD. Ova institucija je globalno aktivna, uključujući i Srbiju i zemlje u regionu.

Osnovno grupisanje think tank institucija bi moglo biti izvršeno na sledeći način:

- Nezavisne think tank institucije civilnog društva osnovane kao neprofitne institucije,

- Think tank institucije za istraživanje politike povezane sa univerzitetima,

- Think tank institucije organizovane/sponzorisane od strane vlada/ država,

- Think tank institucije kreirane, odnosno vođene od strane kompanija, i druge.

U cilju podrobnijeg sagledavanja profila i prioriteta delovanja, think tank institucije se mogu klasifikovati kako sledi:

- Prema veličini na: velike i univerzalne, velike i specijalizovane, i male;

- Prema osnivačima na: pojedince, kompanije, fondacije (zadužbine), vlade, fondove i druge;

- Prema modelu delovanja na: ugovorni odnos sa osnivačem, savetnička uloga, nezavisno istraživanje, lobiranje itd.;

- Prema periodu angažovanja na: dugi rok ili kratki rok (npr. u slučaju kampanja);

- Prema formalnom odnosu sa političkim establišmentom i/ili partijama i koalicijama u matičnoj zemlji itd. 
Sjedinjene Američke Države - SAD imaju dugu tradiciju u sferi think tank institucija. Svakako najstarijom think tank institucijom u toj zemlji se smatra Karnegijeva zadužbina za međunarodni mir (eng. Carnegie Endowment for International Peace) osnovana 1910. godine. Takođe se po svom značaju izdvaja Brukings institucija (eng. Brookings Institutions) osnovana 1916. godine. Formiranje navedenih institucija bilo je praćeno angažovanjem uticajnih investicionih bankara i drugih poslovnih ljudi, kao i akademika i političara.

Savremena praksa think tank institucija u SAD poznaje tri modaliteta. Prvi modalitet čine akademske think tank institucije, koje se prevashodno bave akademskim razmatranjima tema u fokusu, uz izraženu nezavisnost u svom delovanju. Sledeći modalitet predstavljaju državne think tank institucije, koje se u u prvom redu angažuju u odnosu na vladu i dominatno su finansirane od strane same države. Takve think tank institucije se mogu osloniti na pomoć državnih organa, pri čemu je nepisano pravilo da rezultati njihovih istraživanja nisu javno dostupni, tj. publikovani. Treći modalitet je zastupnički, tj. advokativni koji, za razliku od prethodna dva pomenuta, svoju aktivnost retko temelji na sopstvenim istraživanjima. Naime, glavna funkcionalnost pristupa je u marketingu i u inoviranim izdanjima, odnosno prezentacijama već postojećih ideja. Reč je, dakle, o određenim političkim ili ideološkim linijama koje se agresivno promovišu sa ciljem da utiču na političke debate. Neki analitičari ovakav vid angažovanja upoređuju sa lobiranjem, uzimajući kao argumentaciju da timovi iz ovakvih institucija intenzivno koriste medijska saopštenja, a da se fokusiraju na kratkim, sažetim materijalima koje donosioci odluka, zbog svojih brojnih obaveza, mogu da pročitaju između dva sastanka.

Poznato je da u Sjedinjene Američke Države upravo think tank institucije služe za obrazovanje zajednica/klubova eksperata, čiji članovi kasnije kao službenici Vlade postaju deo Uprave, tj. Administracije, putem već uhodanih neformalnih procedura, tzv. efekta odskočne daske.

Velika Britanija ima dugu tradiciju u vezi sa think tank institucijama. Isto važi i za saradnju sa think tank isntitucijama iz SAD. Među brojnim think tank institucijama u Velikoj Britaniji posebnu pažnju zaslužuje Institut Adam Smit (eng. The Adam Smith Institute). Adam Smit je bio škotski ekonomista, filozof i autor, pionir političke ekonomije. U ekonomskoj teoriji smatra se "ocem ekonomije“ ili "ocem kapitalizma“. Ova think tank institucija, kao nezavisna, neprofitna i nestranačka institucija, radi na promociji ideja neoliberalnog i slobodnog tržišta putem izdavaštva, medijskih komentara i edukativnih programa. Danas je ovaj Institut okosnica stvaranja primera slobodnih tržišta i slobodnog društva u Velikoj Britaniji.

U značajnije think tank institucije u Velikoj Britaniji danas spadaju i: COMMUNITY (zajednica, od latinske reči civitas), People (Narod, od grčke reči demos), Institut za istraživanje javne politike (eng. the Institut for Public Policy Research), Policy Exchange (Razmena politika) i Reform (Reforma). U Srbiji je inače posebno aktivna think tank institucija Chatham House poznata i pod imenom Kraljevski Institut za međunarodne poslove iz Velike Britanije.

Godine 1994. sa sedištem u Londonu je osnovan Z/Yen koji predstavlja komercijalnu think tank instituciju, konsultantsku kuću i venture firmu. Isti se angažuje u finansijskim uslugama, tehnologiji i u volonterskom sektoru na 
istraživanju, praćenju performansi i strateškom upravljanju. Z/Yen je razvio Indeks globalnih finansijskih centara. Većinu svojih istraživanja slobodno objavljuje na sopstvenoj web-stranici, dakle bez naknade za korisnike.

Pažnje vredno je spomenuti i think tank instituciju u sastavu Muzeja nauke u Birmingemu. Ovaj think tank raspolaže sa impresivnom kolekcijom od preko 200 eksponata i artefakata, te pruža izvanredan uvid u istoriju razvoja industrije, a posebno automobilskih motora i tekstilnih mašina. Brojni inovativni programi i istraživanja ovog think tank-a pobuđuju veliku pažnju, kako stručne javnosti, tako i šire publike.

Brisel, kao primarno sedište Evropske unije je istovremeno sedište velikog broja međunarodnih think tank institucija. Svakako najznačajnije među njima su: Bruegel, Centar za evropske političke studije (eng. Centre for European Policy Studies - CEPS), Centar za novu Evropu (eng. Centre for the New Europe - CNE), Evropski centar međunarodne političke ekonomije (eng. European Centre of International Political Economy-ECIPE), Evropski politički centar (eng. European Policy Centre - EPC) i neki drugi.

Bruegel predstavlja think tank posvećen istraživanju politike o ekonomskim temama. Isti je počeo sa radom 2005. godine. Predsednik Upravnog odbora ove institucije je gospodin Žan-Klod Triše, koji je bio Predsednik Evropske Centralne banke u periodu od 2003-2011. godine. Bruegel trenutno sprovodi istraživanja u pet oblasti:

- Evropska makroekonomija i upravljanje - sa fokusom na pitanja evropske fiskalne, ekonomske, bankarske i političke unije.

- Globalna ekonomija i upravljanje - ispituje implikacije odnosa između globalnih i EU učesnika i studije za međunarodnu ekonomiju, sa posebnim akcentom na razvoj Azije;

- Finansije i finansijska regulativa, uključujući nadzor i odlučivanje, kako na međunarodnom planu, tako i na nivou EU;

- Inovacije i konkurencija - analize uloge IT-tehnologija, politika konkurencije i tehnoloških inovacija na ekonomske efekte i rast;

- Energija i klima - sa akcentom na istraživanju bezbednosti energije, energetske efikasnosti, te integrisanih tržišta energije, i druge.

Ovaj think tank je prepoznat kao najbolji think tank međunarodne ekonomije na svetu i kao drugi najbolji think tank na svetu, a prema Izveštaju 2019 Global Go To Think tank Report. Izveštaj je sačinjen u okviru Programa istraživačkih centara i civilnih društava (eng. The Think tank and Civil Societies Program - TTCSP). Ovaj Program predstavlja neprofitni program Univerziteta Pensilvanije sa sedištem u Filadelfiji, SAD. Isti upravlja istraživanjem politika instituta širom sveta i raspolaže sa datotekom od približno 6,300 think tank institucija širom sveta.

U Nemačkoj se pojmom think tank, tj. fabrike misli (nem. Denkfabrik) označavaju institucije, koje utiču na oblikovanje javnog mnenja putem istraživanja, razvoja i vrednovanja političkih, socijalnih i privrednih koncepata i strategija, uz promovisanje istih u smislu predloga, preporuka odn. direktnih savetovanja o politikama. $U$ tom pogledu neke fabrike misli zastupaju određene konkretne političke, odnosno ideološke linije i/ili koncepte, sa ciljem da 
ostvare uticaj na političke diskusije. Fabrika misli može biti organizovana kao fondacija, udruženje, neprofitno društvo sa ograničenom odgovornošću, društvo sa ograničenom odgovornošću ili kao neformalna grupa. Obično su u njima zaposleni naučni radnici - eksperti iz oblasti privrede i socijalnih politika, stručnjaci iz oblasti propagande/oglašavanja i komunikacija, kao i trenutno aktivni ili nekadašnji političari, privrednici, preduzetnici i takozvani svedoci, tj. osobe od integriteta sa učešćem u nekim značajnim događanjima.

U Nemačkoj se fabrike misli pretežno finansiraju od strane države, na primer od strane Naučne zajednice Gotfrid-Vilhelm-Lajbnic (nem. Wissenschaftsgmeinschft Gottfried-Wilhelm-Leibniz) sa sedištem u Berlinu, koju trenutno čini 96 ne-univerzitetskih think tank institucija i uslužnih institucija u oblasti nauke. Ovu instituciju takođe čine institucije koje pretežno stavljaju na raspolaganje infrastrukture za naučni rad. Uz to ovaj think tank ima jednu dodatnu specifičnost, utoliko što u njega spada i osam istraživačkih muzeja.

Drugi segment finansiranja think tank institucija u Nemačkoj potiče iz državnih sredstava, kao što je to slučaj kod političkih fondacija. U tom su smislu sve vodeće političke stranke, bez izuzetka, tesno povezane sa fondacijama - istraživačkim centrima koji imaju određenu ulogu u kreiranju politika i to prvenstveno u smislu pružanja podrške kreatorima politika. U najznačajnije spadaju: Fondacija Konrad-Adenauer-Stiftung uz Hrišćansko-demokratsku uniju (nem. Die Christlich Demokratische Union Deutschlands - CDU), Fondacija Friedrich-Ebert-Stiftung uz Socijalno-demokratsku partiju (nem. Die Sozialdemokratische Partei - SPD), Fondacija Hanns-Seidel-Stiftung uz Hrišćansko-socijalnu uniju (nem. Die Christlich-Soziale Union - CSU), Fondacija Heinrich-Böll-Stiftung uz Zelene (nem. Die Grüne), Fondacija Friedrich Naumann Stiftung uz Slobodnu demokratsku partiju (nem. Die Freie Demokratische Partei - FDP) i Fondacija Rosa Luxemburg Stiftung uz Partiju Levica (nem. Die Linke). Spomenute fondacije su aktivne ne samo u svojoj matičnoj zemlji, već i u inostranstvu. S tim u vezi treba konstatovati da su upravo sve gorenavedene fondacije angažovane i u Srbiji.

Pored gorenavedenih, u Nemačkoj postoje i neki privatno finansirani istraživački centri koji dobijaju materijalnu podršku od strane političkih partija, udruženja, firmi, saveza ili privatnih lica.

Pre nego što se pređe na predstavljanje think tank institucija u Srbiji, sledi napomena da u srpskom jeziku ne postoji ekvivalentan izraz za think tank. U praksi se, pored pojma istraživački centar, sreću i pojmovi trust mozgova, centar za pružanje intelektualnih usluga i sporadično još neki izrazi.

Praksa osnivanja i delovanja think tank institucija u Srbiji je novijeg datuma. Najveći broj postojećih think tank institucija je angažovan u oblasti evropskih integracija, međunarodnih i spoljnih odnosa, te socijalne politike, a znatno manji broj u oblasti ekonomije i zaštite životne sredine.

Evropski pokret u Srbiji - EpuS je udruženje građana osnovano 1992. godine, sa željom da inicira i prati sveobuhvatan proces evropskih integracija Republike Srbije. Cilj delovanja Evropskog pokreta u Srbiji je izgradnja demokratske i moderne Srbije u ujedinjenoj Evropi. 
Fond za razvoj ekonomske nauke - FREN (eng. The Foundation for the Advancement of Economics - FREN) je osnovan 2005. godine od strane Ekonomskog fakulteta u Beogradu. FREN se pozicionirao kao jedna od vodećih think tank institucija u Srbiji i regionu. Ciljevi FREN-a su unapređenje istraživanja u sferi ekonomske i socijalne politike u Srbiji i regionu, omogućavanje pristupa visoko kvalitetnim statističkim i analitičkim podacima za donosioce odluka, kao i širenje savremenog načina razmišljanja o ekonomiji i socijalnoj politici u profesionalnim krugovima i široj javnosti.

Centar za evropske politike - CEP je nezavisna, neprofitna think tank organizacija koju je osnovala grupa stručnjaka u oblasti evropskog prava, ekonomije i javne uprave, sa zajedničkim ciljem da doprinesu unapređenju okruženja za kreiranje javnih politika u Srbiji, tako što će ga učiniti transparentnijim i inkluzivnijim, zasnovanim na činjenicama i suštinski orijentisanim ka EU.

U decembru 2018. godine, Centar za evropske politike - CEP je započeo realizaciju dvogodišnjeg projekta Jačanje kapaciteta organizacija civilnog društva za aktivno učešće u pregovorima o pristupanju EU kroz određene radne grupe Nacionalnog konventa o EU (Pripremite se za učešće - P2P) zajedno sa Nacionalnom alijansom za lokalni ekonomski razvoj - NALED i Centrom za savremenu politiku - CSP kao partnerima na ovom projektu.

Brojnost think tank institucija, njihova globalna rasprostranjenost kao i trendovi daljeg razvoja upućuju na veliku zainteresovanost stručne i šire javnosti za njihovo angažovanje, domete i perspektivu.

\section{Literatura:}

1. McGann, James (2006) Comparative Thinktank, Politics And Public Policy, Northampton, MA: Edward Elgar Publishing https://web.archive.org/ web/20060509013941/http://www.ncpa.org/pub/special/20051220-sp.html datum pristupa: 19.06.2020.

2. Bruegel The European think tank specialised in economics, Brisel, Belgija http://www. bruegel.org/ datum pristupa: 20.06.2020.

3. Evropski pokret u Srbiji http://www.emins.org/o-epus-u/vizija/ datum pristupa: 21.06.2020.

4. Fondacija za razvoj ekonomske misli - FREN, Beograd https://fren.org.rs/ datum pristupa:20.06.2020.

5. Centar za evropske politike - CEP, Beograd www.cep.org.rs datum pristupa: 20.06.2020. 


\section{Think Tank}

\section{Radmila Gaćeša}

e-mail: radmila.gacesa@gmail.com

Translation provided by the author
Summary: Think tank is a global phenomenon of the modern world. Globally, out of over 6,300 think tank institutions that existed in 2009, more than half were established after 1989. Foreign financial support for the creation of think tank institutions in Eastern Europe significantly contributed to this increase. Think tank institutions differ from each other according to their ideological approach, sources of funding, topics or the areas they deal with, as well as the users of their services. Think tank institutions are generally competing for influence in politics, business, science, media and society.

A dominant number of think tank institutions deal with topics from politics, social policy, the sphere of economy and business, integration, etc. There is an increasing number of think tank institutions dedicated to social and environmental issues.

The number of think tank institutions, their global distribution, as well as the trends of further development are indicating a great interest of the professional and general public for their engagement, scope and perspective.

Keywords: think tank, politics, research, foundations, energy, government, public, lobbying, climate

JEL: 100, Q40, Q50, Y80 
Think tank is a global phenomenon of the modern world. The term "think tank" originated during World War II and included two determinants: a place that is safe forconversations, hencewithoutthe risk of eavesdropping(tank)and where civilian and military experts worked together on military strategies (think). During the $60^{\prime}$ s and $70^{\prime}$ s of the $20^{\text {th }}$ century, this term began to be used to denote research institutions, which are oriented towards practice outside the framework of security policy. Such activities include presenting the results of the research, as well as determining the settings of the action program and promoting selected topics, among which the following are most focused: social policy, economy, political strategy, technology, security, climate, culture and some others.

Globally, out of over 6,300 think tank institutions that existed in 2009, more than half were established after 1989. Foreign financial support for the creation of think tank institutions in Eastern Europe significantly contributed to this increase.

Think tank institutions differ from each other according to their ideological approach, sources of funding, topics or the areas they deal with, as well as the users of their services. Think tank institutions are generally competing for influence in politics, business, science, media, and society.

A dominant number of think tank institutions deal with topics from politics, social policy, the sphere of economy and business, integration, etc. There is an increasing number of think tank institutions dedicated to social and environmental issues. Among them, the Tellus Institute, a non-profit institution based in Cambridge, Massachusetts, USA, stands out. This institution is globally active, including Serbia and countries in the region.

The basic grouping of think tank institutions could be presented as follows:

- independent civil society think tanks established as non-profit institutions,

- think tanks for policy research related to universities,

- think tanks organized/sponsored by governments/states,

- think tanks created or managed by companies, and some others.

In order to take a closer look at the profile and priorities of think tank institutions, they can be classified as follows:

- According to size: large and universal, large and specialized, and small:

- According to its founders: individuals, companies, foundations (endowments), governments, funds and others;

- According to the action model: contractual relationship with the founder, advisory role, independent research, lobbying, etc.;

- According to the period of engagement: long term or short term (e.g. in the case of campaigns);

- According to the formal relationship with the political establishment and/or parties and coalitions in the home country, etc.

The United States of America - USA have a long tradition in the field of think tank institutions. Certainly, the oldest think tank institution in that country is considered to be the Carnegie Endowment for International Peace, founded 
in 1910. The Brookings Institution, founded in 1916, also stands out for its importance. The formation of these institutions was accompanied by the engagement of influential investment bankers and other businesspeople, as well as academics and politicians.

The modern practice of think tank institutions in the USA recognises three modalities. The first modality consists of academic think tank institutions, which primarily deal with academic considerations of topics in focus, with a pronounced independence in their activities. The next modality is represented by state think tank institutions, which are primarily engaged in relation to the government and are predominantly financed by the state itself. Such think tank institutions can rely on the help of state bodies, where the unwritten rule is that the results of their research are not publicly available or published. The third modality is representative or advocacy which, unlike the previous two mentioned, rarely bases its activity on its own research. Namely, the main functionality of this approach is in marketing and in refurbished editions and presentations of already existing ideas. It is, therefore, a matter of certain political or ideological lines that are aggressively promoted with the aim of influencing political debates. Some analysts compare this type of engagement to lobbying, arguing that teams from such institutions use media announcements intensively, to focus on short, concise materials that decision-makers, due to their numerous obligations, can read between two meetings.

It is known that, in the United States, think tank institutions are used to create communities/clubs of experts, whose members later, as employees of the Government, become part of the Management or Administration through already established informal procedures, the so-called revolving door effect.

The UK has a long tradition of think tank institutions. The same goes for cooperation with think tank institutions from the USA. Among the many think tanks in the UK, the Adam Smith Institute deserves special attention. Adam Smith was a Scottish economist, philosopher and author, a pioneer of political economy. In economic theory, he is considered the "father of economy" or the "father of capitalism". This think tank institution, as an independent, non-profit and non-partisan institution, works to promote the ideas of the neoliberal and free market through publishing, media commentaries and educational programs. Today, this Institute is the backbone of creating examples of free markets and a free society in the UK.

The most important think tank institutions in Great Britain today include: COMMUNITY (from the Latin word civitas), People (from the Greek word demos), the Institute for Public Policy Research, Policy Exchange and Reform. The think tank institution Chatham House also known as the Royal Institute of International Affairs from Great Britain is especially active in Serbia.

In 1994, Z/Yen was founded in London, as a commercial think tank institution, a consulting company, and a venture firm. It is engaged in financial services, technology and the volunteer sector in research, performance monitoring and strategic management. Z/Yen developed the Global Financial Centre's Index. Most of their research is published on their own website freely, i.e. without user fees. 
The think tank institution within the Museum of Science in Birmingham is also noteworthy. This think tank has an impressive collection of over 200 exhibits and artefacts and provides an outstanding insight into the history of industry development, especially automotive engines and textile machinery. Numerous innovative programs and research of this think tank are attracting a lot of attention from both the professional public and the general public.

Brussels, as the primary seat of the European Union, is also the seat of a large number of international Think tank institutions. Certainly, the most important among them are: Bruegel, Centre for European Policy Studies (CEPS), Centre for the New Europe (CNE), European Centre for International Political Economy (ECIPE), European Policy Centre (EPC) and others.

Bruegel is a think tank dedicated to policy research on economic topics. It started operating in 2005. The President of the Management Board of this institution is Mr Jean-Claude Trichet, who was the President of the European Central Bank in the period from 2003 to 2011. Bruegel is currently conducting research in five areas:

- European macroeconomics and governance - with a focus on European fiscal, economic, banking and political union issues.

- Global Economy and Governance - examines the implications of the relationship between global and EU participants and the study on international economics, with particular emphasis on Asian development;

- Finances and financial regulation, including oversight and decision-making, both internationally and at EU level;

- Innovation and competition - analysis of the role of IT technologies, competition policy and technological innovation on economic effects and growth;

- Energy and climate - with an emphasis on research into energy security, energy efficiency, and integrated energy markets and others.

This think tank is recognized as the best think tank of the international economy in the world and as the second-best think tank in the world, according to the 2019 Global Go To Think Tank Report. The report was prepared within the framework of The Think Tank and Civil Societies Program (TTCSP). This Program is a non-profit program of the University of Pennsylvania based in Philadelphia, USA. It manages policy research institutes worldwide and has a file of approximately 6,300 think tank institutions worldwide.

In Germany, the term think tank or "thought factories" (German: Denkfabrik) relates to institutions that influence the shaping of public opinion through research, development and evaluation of political, social and economic concepts and strategies, with the promotion of the same in terms of proposals, recommendations or direct policy advice. In this respect, some thought factories represent certain specific political or ideological lines and/or concepts, with the aim of influencing political discussions. A thought factory can be organized as a foundation, association, non-profit limited liability company, limited liability company, or as an informal group. Usually, they employ scientists and experts in the field of economy and social policies, experts in the field of propaganda/advertising and communication, as well as currently active or 
former politicians, businessmen, entrepreneurs and so-called witnesses, i.e. persons of integrity who participated in some significant events.

In Germany, thought factories are predominantly funded by the state, for example by the Berlin-based Wissenschaftsgmeinschft Gottfried-Wilhelm-Leibniz, which currently consists of 96 non-university think tank institutions and service institutions in the field of science. This institution also consists of institutions that mostly make the infrastructure available for scientific work. In addition, this think tank has one additional specificity, insofar as it includes eight research museums.

The second segment of think tank financing in Germany comes from state funds, as is the case with political foundations. In that sense, all leading political parties, without exception, are closely connected with foundations research centres that have a certain role in policy making, primarily in terms of providing support to policy makers. The most important are: the Konrad-Adenauer-Stiftung with the Christian Democratic Union (German: Die Christlich Demokratische Union Deutschlands - $C D U$ ), the Friedrich-Ebert-Stiftung with the Social Democratic Party (Die Sozialdemokratische Partei - SPD), HannsSeidel-Stiftung with the Christian Social Union (Die Christlich-Soziale Union$C S U)$, Heinrich-Böll-Stiftung with the Greens (Die Grüne), Friedrich Naumann Stiftung with the Free Democratic Party (Die Freie Demokratische Partei - FDP) and the Rosa Luxemburg Stiftung with the Left Party (German: Die Linke). The mentioned foundations are active not only in their home country, but also abroad. In this regard, we can state that all the above-mentioned foundations are engaged in Serbia as well.

In addition to the above, there are some privately funded research centres in Germany that receive material support from political parties, associations, companies, unions or private individuals.

Before moving on to the presentation of think tank institutions in Serbia, it should be noted that there is no equivalent term for think tank in the Serbian language. In practice, in addition to the term research centre, there are also the terms brain trust, centre for the provision of intellectual services and, sporadically, some other terms.

The practice of establishing and operating think tank institutions in Serbia is more recent. The largest number of existing think tank institutions is engaged in the field of European integration, international and foreign relations, and social policy, and a significantly smaller number in the field of economy and environmental protection.

The European Movement in Serbia - EpuS is an association of citizens founded in 1992, with the desire to initiate and monitor the comprehensive process of European integration of the Republic of Serbia. The goal of the European Movement in Serbia is to build a democratic and modern Serbia in a united Europe.

The Foundation for the Advancement of Economics (FREN) was established in 2005 by the Faculty of Economics in Belgrade. FREN has positioned itself as one of the leading think tank institutions in Serbia and the region. The goals of FREN are to improve research in the field of economic and social policy in 
Serbia and the region, to provide access to high quality statistical and analytical data for decision makers, as well as to spread modern thinking about economics and social policy in professional circles and the general public.

Centre for European Policies - CEP is an independent, non-profit think-tank organization founded by a group of experts in the field of European law, economics and public administration, with the common goal to contribute to improving the environment for policy making in Serbia, by making it more transparent and more inclusive, fact-based and essentially EU-oriented.

In December 2018, the Centre for European Policies - CEP launched a two-year project Strengthening the Capacity of Civil Society Organizations to actively participate in EU accession negotiations through certain working groups of the National Convention on the EU (Prepare to Participate - P2P) together with the National Alliance for Local Economic Development - NALED and the Centre for Contemporary Policy - CSP as partners in this project.

The numbers of think tank institutions, their global distribution, as well as the trends of further development are indicating a great interest of the professional and general public for their engagement, scope and perspective.

\section{References:}

1. McGann, James (2006) Comparative Think Tank, Politics And Public Policy, Northampton, MA: Edward Elgar Publishing https://web.archive.org/ web/20060509013941/http://www.ncpa.org/pub/special/20051220-sp.html Date of access: June, 19th 2020.

2. Bruegel The European think tank specialised in economics, Brisel, Belgija http://www. bruegel.org/ Date of access: June, 20th 2020.

3. Evropski pokret u Srbiji (eng. The European Movement in Serbia) http://www.emins. org/o-epus-u/vizija/ Date of access: June, 21st. 2020.

4. Fondacija za razvoj ekonomske misli (eng. The Foundation for the Advancement of Economics) - FREN, Beograd https://fren.org.rs/ Date of access: June, 20th 2020.

5. Centar za evropske politike (eng. Centre for European Policies) - CEP, Beograd www. cep.org.rs Date of access: June, 20th 2020. 